\title{
Gender Discrimination in India
}

\author{
Dr.E.Raju, M.A., M.Phil., Ph.D., Post Doctoral Fellow \\ Dept of Economics Acharya Nagarjuna University Nagarjuna Nagar.
}

\section{Introduction:}

After independence in India one of the issues which has attractive the attention of the policy makers was gender issues and concerns. Gender issues have become central policy arena. The issues of gender equality and justice assumed added significance in the context of the interface between new economic policy perceptions and gender relations. The gender equity became part of country's strategy for eradicating poverty and human misery. The policy makers are strongly believed that a positive commitment to gender equality and equity will strengthen every area of action to reduce poverty because women can bring new energy and new insights. A lot of debate is going on women and development since last few decades. Several interventions had taken place both at national and international level leading to passing of several loss including loss against physical violence IPC Section 498 (a) and Section 125 for maintenance. The importance of feminism has been steadily growing and gaining intellectual legitimacy.

\section{Developments at Global Level:}

There has been global effort with a strong support from U.N., since 1975 to understand the discrimination and restore status of women through equality, development and peace. The year 1975 was declared as the international year of the women by the United Nations. It organized 4 world conferences on at Mexico in 1975, one at Copan Hagen in 1980, one at Nairobi in 1985 and one at Beijing in 1995. The World Summit for Children 1990, set goals for health, education and nutrition for women and their children. The international conference on nutrition in 1992 held at Rome, emphasized the elimination of malnutrition among women and children. The international conference on population and development in 1994 brought out a link between demographic issues and advancement of women through education, health and nutrition. The 1994 international conference on population and development placed issues of gender at the center of discussion. Thus, several international organizations are trying to promote the advancement of women and their full participation in developmental process and trying to eliminate all forms of discrimination against women.

\section{Developments in India:}

The most deep-rooted forms of gender inequality had been built into the structure of traditional Indian society. Through gender inequality exists a large measure in the society under different dimensions for long time, its importance has grown in the recent times only. In the traditional society the inequality between males and females existed to a large extent. Women were looked down socially, economically and politically. Women became scape goats of many traditions and customs. She was brutally killed in the name of Sathi. The practice of child marriage, Kanyasulkam, Prostitution was taken it granted by society and women has no voice what so ever for centuries together. Women's role was restricted to domestic life especially kitchen work and bearing and rearing of children. She has no place in economic and political activities. Girl children were discriminated in terms of basic necessities of life such as food, clothing and shelter. Woman is the last person in the family to eat. She is the person who does all types of menial jobs. There is no respect for her work. Most of the women's work outside the domestic front is restricted to agricultural labour activity (in agriculture) and unorganized activities in urban sector. The census of India did not consider their work while counting the number of economically active persons in the country for quite a long time.

The Government of India has taken several measures and also making endeavourer to hoist the status of women in the society in order to promote equality of men and women. The different plans, programmes, and policies have laid emphasis on women empowerment and raising the economic, educational, health and political participation of women to match with that of men. The draft national policy on empowerment of women envisages 1) to setup councils at the national and State levels to review the implementation of the recommendations of the national and State Commissions for women. $\quad 2)$ The center and State to draw up time bound action plans to translate this - policy into concrete action in consultation with the Central and State Commissions for women. (3) Every ministry at the Center and the State is obliged ensure equal flow of benefits in physical and financial terms to

Article 15 of the constitution prohibits any discrimination on grounds of sex. The directive principles of State policy also urges that the State shall direct this policy towards securing an adequate means of livelihood for women and ensuring equal pay for equal work for both men and women. Since seventy's the objectives of 
raising the status of women and also been included in different five years plans. In the sixth five year plan emphasis was laid on raising the employment status of women. The seventh plan emphasized the need for human resource development in women. The eighth plan aims at enabling women to function as equal partners and implement social legislation for women effectively. The ninth plan has identified empowerment of women as an objective. The tenth plan also emphasis on women development.

The formulation of the national commission for women (N.C.M.) and the idea of setting of a national council for empowerment of women are encouraging steps in this direction. Also different state governments are also implementing several development measures for women's health in general and re-productive health in particular. The lack of sex education among adult girls and re-productive health education among the married women are also cause of many preventable diseases. Empowering women regarding the own re-productive health care and effecting accountability of men towards women's re-productive health are important for promoting women health status in the society.

Now with the efforts of national and international organizations several laws were passed and some laws were changed. But still women continue to suffer from many social and economic and political disadvantages, since the attitudes did not change as fast as the change in laws. Gender issues are ideologically motivated and need a change in mindset in terms of attitudes and behavior of both men and women of all dimensions.

\section{Objective and Data Base:}

The main objective of the present paper is to examine the gender discrimination in India in demographic social, economic and political context. The data required for the present paper was collected from secondary sources.

The women discrimination can be visualized on various angles. In a male dominated society like ours one has to accept that women are at the receiving end. The sex ratio is unfavorable to women and it has declined overtime. The literacy rates are low among women. The expectation of life is low for women in India up to the recent times. The opportunities and access to decision-making institutions are not equal to both men and women. There is clear division of labour among men and women, designating certain tasks exclusively to each and another. Mostly activities, which have low market value, are attached to women. Women mostly spend their time in household maintenance. There were also gender differences access and control over resources, which were important elements to consider in development, programmes especially where interventions may change the value of resource and reduce women's access.

\section{Gender Ratio:}

Sex is an easily identifiable characteristic and its dichotomous nature presents few problems of classification. The sex structure of any population can be measured through the percentage of males in the population or masculinity proportion or the sex ratio. The sex ratio of the population thus may either be expressed as the number of males per thousand females or as the number of females per thousand males. The former definition is followed all over the world but the Indian census followed the later definition. The sex ratio above thousand indicates a high sex ratio while that below thousand indicates a low sex ratio.

Sex and age are the basic characteristics or the biological attribute, of any demographic group and affect not only its demographic but also its social economic and political structure, for the influence birth and death rate, internal and international migration, marital status composition, man power, the gross national product, planning, regarding educational and medical services and housing, etc. The attitude of society towards children, the youth and elderly people is effected by sex-age distribution of population. Sex and age are also very important because, they are visible, indisputable and convenient indicators of social status. Each individual is ascribed a certain status in society on the basis of sex and age. Similarly her/his expected role in the family and society is associated with sex and age. These are culturally determined and vary from one culture to another. Even with in the same culture, they may under go changes overtime. In the traditional Hindu family status is accorded on the basis of sex and age. Men are more important than women and older persons are more important than younger persons.

Plato, the greatest philosopher (427-347 BC) stated that the highest good was to be achieved; the citystate should have 5040 citizens and did not include women, children and slaves in this ideal number.

The sex ratio in India as always remind unfavourable to females. The sex ratio (M/F) was 1029 of males per 1000 females in 1901 and increased to 1072 in 2001 showing more and more preponderance of males in the population.

The sex ratio of the total population at a point of time is known as the overall sex ratio. Generally the overall sex ratios of the population of most countries fall within the narrow range of about 95 to 105 . Any overall sex ratio out side this range is considered to be extreme and is the result of some unusual circumstances 
such as heavy war causalities, excessive immigration are emigration. In general the overall sex ratios of the developing countries are on higher side while those of developed countries are below 1000.

\section{Factors Affecting overall sex ratio :}

The overall sex ratio is the result of the factors such as, the sex ratio of the new born babies are sex ratio at birth, the sex ratio of the deceased persons and the sex ratio of the net migrants.

Sex ratio at Birth : There is no 1:1 ratio of male and female births. The number of male babies is always slightly higher. Sex ratio of birth is above thousand. There are 105 male babies per thousand female babies. Sex ratio of birth is determined biologically. Nature is slightly more favourable to male at birth. The sex ratio at birth depends upon the sex ratios of two biological antecedent events that is sex ratio at the time conception and sex ratio of fetal losses of deaths. The sex of fetus is determined at the time of fertilization but there is no direct means of observing this ratio at conception. The indirect estimates suggest that the sex ratio at conception known as the primary sex ratio is much higher than the sex ratio of live birth or fetal deaths. The sex ratio of fetal deaths (gestation period of 20 weeks or more). In United States during 1940-44 was higher i.e., 119.8 as compared to that of live births i.e. 105.2. Through the sex ratio at birth is determined primarily by biological factors some demographic factors such as age of mothers and order of live births also influence the sex ratio. There appears to be an inverse relationship between age of the mothers and the birth order of the child on the one hand and the sex ratio at birth on the other. Among the lower order births, specially the first and second order births the sex ratios are higher, which means more male babies are born among the first and second bond. Lower order births are associated with the lower ages of mothers, hence the negative relationship between the age of the mother and the sex ratio of the births. As the sex ratio at birth is higher for first and second order births the result was an increased sex ratio of the births. After the first and second world wars in the European countries the sex ratio at birth had increased and some biologists believed that some meta biological force was in operation. Also, pre birth interventions such as sex selective abortions were performed after the pre determination of the sex of the fetus can influence the ratio at birth. In India, sex selective abortions were more common. A large number of couples practice induced abortions of the female fetus and hence sex ratio at birth has increasingly favourable to male babies.

Sex Ratio of Deceased persons : Differential mortality of the males and females is an important factor affecting the overall sex ratio and the sex ratio at various wages. Data and sex ratio of the dead in various countries indicate that with the exception of India, Pakistan and Bangladesh the value of sex ratios of diseased much above 1000. In other words more than thousand males per thousand females. The male fetus is biologically, more delicate than the female fetus. It means that even after the birth the male baby continues to be biologically disadvantaged. The fact is reflected in the higher male mortality rates not only in the first day, in the first week and in the first month and in the first year but throughout life. In fact, in most countries the crude death rates for males are higher than those of females. It has also been observed that the expectations of life at birth for females are almost universally higher than that for females including India. As age advances the sex ratio exhibits an increasingly numerical access of females according to 1959 census in Soviet Union there are 21 million more females than males. Wars widen the gap between males and females as is observed during the second world war period. The Holy Quraan permitted "Polygamy"(allowing male to marry maximum four females). Because females are access in number and they should not remain unmarried because of shortage of males.

Sex Ratio at Net Migrants: The third factor affecting the overall sex ratio of any population is sex ratio of the net migrants which essentially socio economic in nature. Migration is ordinarily sex selective but it cannot have significant impact on the sex structure of the population. In India, the sex ratio in urban areas is favourable to males because of male domination in internal migration.

Table - 1 Gender Ratio in India, 1901-2001

\begin{tabular}{|c|c|c|c|}
\hline Sl. No. & Year & $\begin{array}{c}\text { Gender Ratio F/M } \\
\text { per 1000 }\end{array}$ & Gender Ratio M/F per 1000 \\
\hline$(1)$ & $(2)$ & $(3)$ & $(4)$ \\
\hline 1 & 1901 & 972 & 1029 \\
\hline 2 & 1911 & 964 & 1038 \\
\hline 3 & 1921 & 955 & 1047 \\
\hline 4 & 1931 & 950 & 1053 \\
\hline 5 & 1941 & 945 & 1058 \\
\hline 6 & 1951 & 946 & 1057 \\
\hline 7 & 1961 & 941 & 1063 \\
\hline 8 & 1971 & 930 & 1075 \\
\hline 9 & 1981 & 934 & 1071 \\
\hline 10 & 1991 & 927 & 1079 \\
\hline 11 & 2001 & 933 & 1072 \\
\hline
\end{tabular}


Source: Census of India 1991, General Population - Part II B(1), Vol. 1.

Sex ratio is a crucial indicator of development in a population. The analysis is mostly used in sociological analysis. India is an exceptional country where females are less in number as compared to males, upto the last century. Women are fewer than men in almost all the states in India, except Kerala. However, the expectation of life for females crossed males in the recent years. In India discrimination against female sex is prevailing centuries together and the situation has deteriorate over time.

The sex ratio in India was presented in Table No. 1. The table reveals that this has declined to 927 in 1991, and increased slightly to 933 in 2001. This is a peculiar manifestation of continuing gender inequality and it accentuations are clearly observed in the Indian scenario. Table 1 and 2 clearly show sex discrimination existing in India and among States during 1901 and 2001. Most of the states in India registered a decline in sex ratio during the last one century. The highest decline was observed in Bihar, Orissa, M.P., Maharastra, Tamil Nadu and Gujarath. The states that have registered an important in the sex ratio are Himachal Pradesh, Kerala and Panjab. However, the deductive in sex ratio is low among the states of Andhra Pradesh, Haryana, Assam and West Bengal. The highest sex ratio is noticed in Kerala and lowest in Haryana in 2001.

Table - 2 Sex Ratios in India and Major States (Female/Malel) 1901 and 2001

\begin{tabular}{|c|l|c|c|c|c|}
\hline \multicolumn{1}{|c|}{ State $(2)$} & $\mathbf{1 9 0 1}$ F/M & 2001 F/M & Change & 2001 M/F \\
\hline$(1)$ & \multicolumn{1}{|c|}{ No. } & $(3)$ & $(4)$ & $(5)$ & $(6)$ \\
\hline 1 & India & 972 & 933 & $(-) 39$ & 1072 \\
\hline 2 & Andhra Pradesh & 985 & 978 & $(-) 7$ & 1022 \\
\hline 3 & Assam & 919 & 932 & $(-) 13$ & 1073 \\
\hline 4 & Bihar & 1054 & 920 & $(-) 134$ & 1086 \\
\hline 5 & Gujarath & 954 & 921 & $(-) 33$ & 1086 \\
\hline 6 & Himachal Pradesh & 884 & 970 & $(+) 86$ & 1131 \\
\hline 7 & Haryana & 867 & 861 & $(-) 6$ & 1161 \\
\hline 8 & Kerala & 1004 & 1058 & $(+) 54$ & 945 \\
\hline 9 & Karnataka & 983 & 963 & $(-) 20$ & 1037 \\
\hline 10 & Orissa & 978 & 972 & $(-) 65$ & 1029 \\
\hline 11 & Maharastra & 990 & 922 & $(-) 56$ & 1085 \\
\hline 12 & Madhya Pradesh & 832 & 847 & $(-) 70$ & 1087 \\
\hline 13 & Panjab & 905 & 922 & $(+) 42$ & 1144 \\
\hline 14 & Rajasthan & 937 & 898 & $(-) 17$ & 1085 \\
\hline 15 & Uttar Pradesh & 1044 & 986 & $(-) 39$ & 1114 \\
\hline 16 & Tamil Nadu & 945 & 919 & $(-) 26$ & 1014 \\
\hline 17 & West Bengal & 9671 & 1071 \\
\hline
\end{tabular}

Source: Census of India 1991 and provisional Population Tables 2001

Sex discrimination is more pronounced among young age groups which is called Jovialitive sex ratio. Sex discrimination exists in the specific age groups especially at the very young ages and in the childhood ages. The childhood sex ratio was 945 in 1991, and 927 in 2001 in India. Similar situation was observed among the different states in India. In Andhra Pradesh in 1991 and it declined to 939 in 2001 and in Kerala the childhood sex ratio was 958 in 1991 and it increased to 963 in 2001.

Factors for paucity of females in India:

1. Higher mortality of females (young girls, maternal mortality, female infanticide)

2. Change in sex ratio at birth (Because of sex selectivity induced abortions) is becoming more and more favourable to men.

3. To a certain extent differential under counting (however differential under counting of girls cannot explain the decline in child sex ratio during 1981-91 and 1991-2001.)

Throughout the census history of India till 1991 the main factor responsible for numerical deficit of females was access female mortality. Praveen Visaria observed that access of males is due to unusually high mortality among females compared to that of males in India. Amarthya Sen felt that there are 37 million women missing in India.

Of more concerned was increase in the sex ratio of child population from 1004 males per 1000 females in 1981 to 1058 males per 1000 females in 1991. The census of India 1991, probe survey noticed that 6 million live births that occurred during 1981-91, the sex ratio at birth worked out to be 1120 boys per 1000 girls. The results of 2001 census further indicated that altogether the overall sex ratio has declined from 1079 males per 1000 females to 1072 in 2001 . The sex ratio of the child population has sharply increased from 1058 in 1991 to 1078 in 2001 . Thus, the proportion of boys among new born babies is increasing sharply and it is commonly assumed to be the result of rapid spread of the use of ultra sound and amniocentesis for sex determination and 
subsequent sex selective induced abortions. Amarthya Sen refers to abortions of female fetus after determination of the sex of the fetus as natality in equality. He designated the use of ultra sound as hi-tech sexism.

The census findings of high sex ratio of young children are confined in the result of the National Family Health Survey - 2 (1998-99) and NFHS-3 (2006). These surveys also showed that ultra-sound amniocentesis are often used for sex determination leading to selective sex abortions consistently over the decade. It is observed by Arnold, Kishore and Roy that the legislation protecting the test of pre-sex determination has failed. What is needed is a change the basic conditions such as strong and persistent son preferences, the generally low status of women, white spread practice of dowry and considerable acceptance of sex selective abortion.It is well known that both the structure of the Indian economy, polity and society and path of development pursued so far have served to sustain exuberant inequality among dimensions. One such important dimension is gender inequality. Reproduction often becomes a determinant of the status of women in our society. Today there is a need to give out health care system from curative to preventive. Health problems of adolescent and young adults of both the sexes vary widely. 'Catch them young' is a slogan widely recommended to bring about desired attitudinal changes for gender equality.

Table - 3 Life Expectancy at Birth in India 1951-93

\begin{tabular}{|c|c|c|c|c|c|}
\hline Sl. No. & Year & \multicolumn{2}{|c|}{ Life expectancy at Birth (year) } & Abs. Differences \\
\hline & & M & F & M+F & F-M \\
\hline$(1)$ & $(2)$ & $(3)$ & $(4)$ & $(5)$ & $(6)$ \\
\hline 1 & $1950-51$ & 32.4 & 31.7 & 32.1 & $(-) 0.7$ \\
\hline 2 & $1960-61$ & 41.9 & 40.6 & 41.3 & $(-) 1.3$ \\
\hline 3 & $1970-71$ & 46.4 & 44.7 & 45.6 & $(-) 1.7$ \\
\hline 4 & $1980-81$ & 50.9 & 50.0 & 50.4 & $(-) 0.9$ \\
\hline 5 & $1990-91$ & 58.1 & 58.6 & 58.3 & $(+) 0.5$ \\
\hline 6 & $1992-93$ & 60.4 & 61.2 & 60.8 & $(+) 0.8$ \\
\hline 7 & $1996-01$ & 62.3 & 65.3 & 65.6 & $(+) 1.6$ \\
\hline 8 & $2001-06$ & 63.8 & 66.9 & 65.6 & $(+) 1.6$ \\
\hline
\end{tabular}

Source: 1. Economic Survey of India 1996-97

2. HRD 1997, PP. 164.

Index: M- Male F- Female

The World Bank in its recent report pointed out that maternal mortality is very high in India. The World Bank in its report further revealed that there is an excess maternal morbidity and mortality resulting from physical assaults such as rape, burning, beating. The abortion related mortality and morbidity seems to be high especially in the rural areas. The pre-pondarance of illegal unscientific and traditional methods of abortion in rural areas, caused a lot of damage to women's health in general and re-productive health in particular.

The document on national perspective plan for women (1993-2000) of government of India summarizes the health situation of women as was characterized by malnutrition, disease, disability and even death at critical stages of their lives, namely, early childhood. Adolescence, and re-productive phase. Neglect of women's health and nutrition is so serious that it out weighs women's natural biological tendency to live longer than men. 100 Million women are missing every year. Huge investments in the field of health have great importance as far as maintenance of human capital is concerned. Table -3 provides information on life expectancy at Birth for both males and females. The table clearly shows that life expectancy is higher for males as compared to females. However, in the recent times the expectation of life is higher for females as compared to males. During the period 1986-01, the expectancy of life is 62.3 years for males whose as 65.3 years for females. The females have 1.6 years of more life than males and as per the projections, for the period 2001-06, the male expectancy will be 63.8 years and for females 66.9 years and for females 66.9 years.

\section{Maternal Mortality Rate:}

Maternal mortality refers to deaths due to pregnancy related causes. The maternal mortality rate is very high in India (437) in 1994. It shows an increasing tendency. The high rate is attributed to unwanted, unplanned pregnancies, malnutrition, lack of regular medical consultation, lack of knowledge of health care, illiteracy, poverty less access to medical care in proper time women's health in India states that India accounts for almost 25 per cent of world's maternal deaths and number of pregnancy related deaths in rural areas are still highest in the world. Nutrition survey in India, indicates that majority of women in India suffer from anemia and other nutrition deficiencies. A number of children are suffering from health diseases. The maternal mortality is high in India because of social and economic factors. Most of these deaths are preventable because it is only reflection of women's nutrition, poor health states and high fertility of poor acces to utilization of health seminars etc., The accessibility and availability health provides is one of the important factors that determinate maternal mortality. Since prodders must take special care to pregnant adolescents as a high 


\section{Age at Marriage:}

The age of marriage is very low in India. Universality of marriage and child marriages are very much prevalent in India. Even though Sarada Act was passes as early as 1929 with a view to eliminate child marriages and uplift the dignity of women still 50 per cent of the women in the country are getting married less than the legal age of marriage (18 years). The prevalence of spinster ship is very less in India since it is associated with social stigma. Even women who are physically and mentally handicap also get marry for some reasons or the other.

Table - 4 Age at Marriage in India 1951-1991

\begin{tabular}{|c|c|c|c|c|c|}
\hline Sl. No. & Year & \multicolumn{2}{|c|}{ Mean age at Marriage } & \multicolumn{2}{|c|}{ Absolute increase (years) } \\
\hline & & Male & Female & Male & Female \\
\hline$(1)$ & $(2)$ & $(3)$ & $(4)$ & $(5)$ & 0.7 \\
\hline 1 & 1961 & 21.6 & 16.1 & 1.7 & 1.1 \\
\hline 2 & 1971 & 22.4 & 17.2 & 0.8 & 1.1 \\
\hline 3 & 1981 & 23.3 & 18.3 & 0.9 & 0.4 \\
\hline 4 & 1991 & 23.8 & 18.7 & 0.5 & 1.5 \\
\hline 5 & 1992 & 25.0 & 20.0 & 1.4 & \\
\hline
\end{tabular}

Source: S.N. Agarwala, India's Population Problems, Magrow hill, New Delhi, 1981.

Table 4 provides information on age at marriage in India. The marriage is low for females as compared to males. Though the absolute increase in the age of marriage is high as compared to males still there is need for increased age of marriage for men in India as it is associated with social and economic development of the women.

He recommended that women should not get married between the ages of 16 and 20 and marriage is made compulsory between these ages. In ancient Spartha, marriage considered as an institution created by the legal and political system to provide the state with inhabitants and citizens. The real purpose of marriage was procreation of children. Celibacy was punishable by law and denounced in public. Athenian customs and laws encouraged frequent child bearing. When over population occurs Greeks encouraged abortion and exposure to new born babies leading infanticide.

Traditionally the Hindu religion has laid stress on marriage and begetting of children. Even today marriage is universal. A man after Brahmacharyam (a period of pursuit of knowledge as student) enters Grihasthasharam by getting married. The aims of Hindu marriage are Dharma, Praja (progeny) and Rathi (pleasure). For the women marriage is essential because though a man goes through several sacraments throughout his life, marriage is only sacrament that she is allowed. Procreation is the second aim of Hindu marriage and brining forth a son is necessary since putra is needed to save parents from Punnaminaraka (Hell). Daughter is only desire because kanyadanam adds to the punya of the parents. The newly married Hindu couples have therefore received blessings from their elders "may you have eight sons and five daughters". Then itself there is lot of discrimination between in the possession of getting children. Till recently the Hindu could legally have more than one wife, one of the main reasons for securing the second wife being childlessness.

\section{Early Child Bearing and Other Social Factors:}

Early child bearing is associated with high risk of pregnancy since women will not attain proper physical and mental maturity by that time. Spontaneous abortions, fetal deaths are very high among women getting married early. The prevalence of primary sterility is also very high among women marrying below 18 years of age. Early child bearing is the one of the reasons for high maternal mortality in the country.

Fertility is very high in India, as compared to other developing countries. Greater frequency of births will lead to higher maternal mortality. Several studies show that maternal mortality is high among women having high parity. Spacing of children is associated with less maternal mortality. More the spacing less the risk of maternal mortality and vice versa. The postpartum amenorehea is also very low in India. The tradition of breast-feeding the child is slowly disappearing and most children now a days are bottle fed rather than breastfed. Most of the deliveries take place at home and not in the hospitals. Hospital deliveries are safer as compared to home deliveries. Most of the deliveries are attended by local Mantrasaani or relative rather than a doctor or a nurse. The umbilical card is being cut by traditional knife and not by any sterilized material. There is proper pre-natal or anti-natal care. Since female literacy is very low many women do not have the knowledge of conception, child bearing and rearing. They do not know how a child is born. The human anatomy and physiology is not at all known to many women in the country. Majority of the women in the country still believe that children are God given andthey are only instrumental. They believe in the concept "Naru posina vaadu Neerupoyyada ?". Instead taking proper pre-natal and anti-natal care they depend on God for every thing thus all these factors led to high maternal mortality in the country which in turn reflected in the low and declining sex ratio. 


\title{
Feticide:
}

A number of factors including neglect of female infants and children and greater male rather than female access to improved health care and education are responsible for declines in sex ratios. The decline in sex ratio at birth is due to the practice of female feticide (identifying the sex of the fetus and Killing) and practice of female infanticide that killing of an infant because it is a female. Though foeticide is a recent development, female infanticide is much longer history in India.

\begin{abstract}
Abortion:
Abortion is as old as man. Both spontaneous and induced abortions were prevalent for long time India. In 1970s a survey conducted in Bombay hospitals revealed that 12 per cent of women who were admitting for medical termination were teenagers of less than 18 years of age and 92 per cent of them are unmarried. In the case of rape and in unforeseen social and economic, circumstances abortion is the only alternative. Because of high incidence of abortion, women's health is affected. Even though the risk associated with normal abortions is not very high, but repeated abortions are associated with high risk of mortality and morbidity. Female foesticide is of recent origin in our country, since the technology for identifying the sex of the fetus has come into use only recently and the necessary facilities are confined to mostly to urban areas.
\end{abstract}

\section{Female Infanticide:}

Murder or deliberate neglect of infant to induce death has been known to occur to many human societies across space and time. The wide spread practice of infanticide in $19^{\text {th }}$ century in India was extensively documented in the literature on British India, especially in North India. Even though female fetus is biologically stronger than male fetus in practice there are less girl children than male children. Female infanticide has spread widely in rural areas. The practice of female infanticide cannot be tackled in isolation. It is an extreme and particularly reprehensible form of violence against women in our society. In the long run only a broad and successful movement to transform the structure and policies of our economy and society in a democratic direction can eliminate all forms of violence against women. To tackle the problem of over population Plato recommended infanticide, exposure and abandonment of deformed infants on grounds of eugenics.

\section{Infant Mortality:}

Infant mortality is considered to be a fairly sensitive index of the health condition of population in a society. it is affected by both biological and environmental factors. Apart from genetic factors, the age of the mother, order of birth, spacing of children play a very significant role in determining the level of infant mortality in society.

Infant mortality in India has declined over time. The rate was 146 in 1951 and 1961, 129 in 1971, 110 in 1981, 80 in 1991 and 70 in 2001. the infant mortality rate is very high among female children as compared to male children. Health care is very poor among female children as compared to male children leading to high infant mortality among female children. the decline in infant mortality is a precondition for acceptance of small family norm in the country.

\section{Child Mortality:}

Child mortality refers to mortality in less than 5 years of age for 1000 live births. Childhood deceases, child malnutrition, lack of safe drinking water, are some are the reasons for child mortality in India. The child mortality rate is very high among female as compared to male children. during the period 1979-81, the male child mortality was 41 as against female mortality of 44.8 similarly during 1989-91 the male child mortality was 26.3 as against 26.9 among females in India. There exists clear discrimination in child mortality between male and female children and there is every need to curb the same.

\section{Son Preference:}

In patriarchal society there is strong son preference. The desire is in line with aspirations emerging from an increasingly consumerist culture leading to practice of female foeticide. People believe that son is preferred to save parent from 'Punnai Narakam'. Son is preferred to maintain family's surname and hire ancestral property. Strong preference for male child reflected in health care. The birth of a male child is a cause for celebration, while the birth of female child is a state of commensuration. Thus, son preference leads to low sex ratio in India.

\section{Family Planning Acceptance:}

Women bare gigantic share of family planning burden especially in the rural India. The complications arising after tubectomy and IUD and side effects of oral pills have further shacked the health of the rural women. Male members are not coming forward to share the burden of family planning. There is a myth and 
fear among people that men will become impotent by undergoing vasectomy operation. That is most of women along care under going family planning operations. That is most of the women along are under going operations. Due to poverty some women are becoming victims of STD, TB, Goiter, etc. Thus, women's health is affected finally leading to low sex ratio in the country.

\section{Under Counting of Women:}

One of the main reasons for gender inequality in India may be under counting of women in India. There is lot of social stigma associated with counting of women. The information with regard to female members of the family is mostly kept secret as compared to men. There is lot of bias and under reporting about women due to cultural factors. In a family where there are only daughters the possibility of under reporting is very high. If they are divorced women or widowed women in the family, the possibilities of under reporting are also high. Thus, under counting is one of the main reasons for enumeration of low females in the country.

Thus all these factors put together has led to gender inequality in India. There is need to empower the women in India by bringing changes in the reproductive health of women. Also there is need to empower the women through social, economic and political measures.

\section{Social Inequalities:}

Women are discriminated against men historically in terms of education, health and social justice. Education plays a crucial role in improving the possibilities for personal growth. Similarly, cultural norms, values, and customs are no less important in determining the women's life choices and physical and mental well being. The linkages between the culture, women's education and health are important to improve the status of women in the society.

\section{Literacy:}

Literacy is the crucial social sector component and women are totally neglected until recent times in this sector. Illiteracy is a root cause for all other types of discriminations. Female literacy rate was less than 10 per cent before attaining independence in India. The rate was 0.69 per cent in 1901, 1.05 per cent in $1911,1.81$ per cent in 1921, 2.93 per cent in 1931, 7.3 per cent in 1941, and 8.86 per cent in 1951. In 1961 hardly 15.34 per cent of women are literate. As per 2001 census, 54.16 per cent of women are literate. Table 5 provides information on literary throughout the century in India. Similarly Table -6 provides information in enrolment of students in India at the Primary, Middle and High school level. The table clearly shows that the enrolment ratios are much lower for girls as compared to boys form primary to high school level. Table -6 provides information on the enrolment of students at secondary level in the rural and urban areas. Gender inequalities exists not only in the rural areas but in urban areas too. Even though female literacy has grown over the past century, a number of females who remained as illiterate increased overtime. There were hardly about 10 crores women who were illiterate ( 0.69 per cent) in 1901 . But there are about 23 crores women who are illiterate in 2001. the illiteracy level in absolute terms has almost doubled even though literacy rate has increased over time. We all believe that if one male person in the family is literate, he along is literate, where as if one women in the family is literate the entire family will be literate.

Table - 5 Literacy Rate in India - 1951-2001.

\begin{tabular}{|c|c|c|c|c|}
\hline Sl. No. & Year & \multicolumn{3}{|c|}{ Literacy population in Percentage } \\
\hline & & Male & Female & Total \\
\hline$(1)$ & $(2)$ & $(3)$ & $(4)$ & $(5)$ \\
\hline 1 & 1951 & 27.2 & 8.9 & 18.4 \\
\hline 2 & 1961 & 40.2 & 22.0 & 28.3 \\
\hline 3 & 1971 & 46.0 & 28.5 & 34.5 \\
\hline 4 & 1981 & 53.4 & 28.5 & 41.4 \\
\hline 5 & 1991 & 64.2 & 39.2 & 52.2 \\
\hline 6 & 2001 & 75.9 & 54.2 & 65.4 \\
\hline
\end{tabular}

Source: Census of India 1991 and provisional Population tables 2001

Table - 6 Progress of Enrolment in India 1950-'51-'97-'98 (In lakhs)

\begin{tabular}{|c|c|c|c|c|c|c|c|c|c|c|}
\hline \multirow[t]{2}{*}{ Sl. No. } & \multirow[t]{2}{*}{ Year } & \multicolumn{3}{|c|}{ Primary I-V } & \multicolumn{3}{|c|}{ Middle VI-VIII } & \multicolumn{3}{|c|}{ High School } \\
\hline & & Boys & Girls & Total & Boys & Girls & Total & Boys & Girls & Total \\
\hline (1) & (2) & (3) & $(4)$ & $(5)$ & $(6)$ & $(7)$ & $(8)$ & (9) & (10) & (11) \\
\hline 1 & $1950-51$ & 13.8 & 5.4 & 19.2 & 2.6 & 0.5 & 3.1 & 1.3 & 0.2 & 1.5 \\
\hline 2 & $1960-61$ & 23.6 & 11.4 & 35.0 & 5.1 & 1.6 & 6.7 & 2.7 & 0.7 & 3.4 \\
\hline 3 & $1970-71$ & 35.7 & 21.3 & 57.0 & 9.4 & 3.9 & 13.3 & 4.9 & 1.7 & 6.6 \\
\hline 4 & $1980-81$ & 45.3 & 28.5 & 73.8 & 13.9 & & 20.7 & 7.6 & 3.2 & 10.8 \\
\hline 5 & $1990-91$ & 58.1 & 41.0 & 99.1 & 20.9 & 12.4 & 33.3 & 14.0 & 6.9 & 20.9 \\
\hline 6 & $1997-98$ & 44.0 & 33.4 & 77.4 & 36.6 & 19.1 & 45.7 & 31.9 & 21.0 & 52.9 \\
\hline
\end{tabular}


Source: Fourth World Conference a Women, being 1995.

The directive principles of the constitution of India exhorts the state to endeavor to provide free and compulsory education to all the children upto age 14 . the state was directed to achieve such an objective by 1960 , but four decades later the situation continues to be dismal with nearly 50 per cent or 10 crores children (614 years) mostly are out of schools. The $83^{\text {rd }}$ amendment bill fulfills the need for more compelling and stringent action on the part of the Government. Compulsory primary education has remained as an unattainable goal. Since elementary education is a concurrent subject, the major responsibility for achieving universal education lies with State Governments.

Table - 7 Enrolment at Secondary Level Education Rural and Urban Gender wise Differences

\begin{tabular}{|c|c|c|c|c|c|c|c|}
\hline SI. No. & Year & \multicolumn{3}{|c|}{ Rural Percentage } & \multicolumn{3}{c|}{ Urban Percentage } \\
\hline & & Boys & Girls & Total & Boys & Girls & Total \\
\hline$(1)$ & $(2)$ & $(3)$ & $(4)$ & $(5)$ & $(6)$ & $(7)$ & $(8)$ \\
\hline 1 & 1961 & 9.25 & 2.47 & 11.72 & 22.25 & 14.51 & 37.76 \\
\hline 2 & 1971 & 22.43 & 8.77 & 31.20 & 32.80 & 24.82 & 57.62 \\
\hline 3 & 1981 & 23.75 & 10.85 & 34.60 & 32.10 & 26.43 & 58.63 \\
\hline
\end{tabular}

Source: Census Report.

Articles 15 of the constitution prohibits any discrimination on ground of sex. In 1958 Government of India appointed a committee on women's education in order to recommend special measures to bridge the gap between boys and girls at the primary and secondary levels. The national policy on education 1968 also laid emphasis on removal disparities in education opportunities to women. Education of women can be affective tool for women's empowerment. The draft national policy for empowerment of women envisized that measures will be taken to eliminate discrimination eradicate illiteracy, increase enrolment and retention rates and improve quality of education among women. There is need to implement measures to develop educational standards, taught the basics of primary health care, environmental sanitation use of safe drinking water and reproductive health care. There is every need to built positive attitudes among women. Separate schools, colleges, and other higher education institutions may be started exclusively for women, for educational purposes. These measures will help to increase literacy and education among women in the country.

\section{Women and work participation :}

In the west before industrial revolution the roles of men and women are well defined as man for plough and the women for the hearth. But, today situation has changed and many women gainful employment, though men have not taken house keeping. The roles and status of individuals affects the demographic situations.

As per ILO report women constitute roughly 50 per cent of the total population, 33 per cent of labour force and perform 66.6 per cent of total work hours. They earn only 10 per cent of total income and less than 1 per cent of world's property. Lack of owner ship rights insecurity in employment, under employment; extended hours of work are the common sticks characters of the Indian women. Most of the Indian women are engaged in domestic work mostly non-remunerative in nature. They work in organized sector and paid very less. Table -8 provides information on women working in the organized sector in India during 1971-91. The table shows that there exists clear discrimination in employment of men and women both in public and private sectors during 1971-91. As compared public sector, private sector provides better employment opportunities in India.

Table -8 Women in Organized Sector in India

\begin{tabular}{|c|c|c|c|c|c|c|c|}
\hline $\begin{array}{c}\text { Sl. } \\
\text { No. }\end{array}$ & Year & $\begin{array}{c}\text { Public } \\
\text { Sector }\end{array}$ & $\begin{array}{c}\text { Private } \\
\text { Sector }\end{array}$ & Total & \\
\hline & & Male & Female & Male & Female & Male & Female \\
\hline$(1)$ & $(2)$ & $(3)$ & $(4)$ & $(5)$ & $(6)$ & $(7)$ & $(8)$ \\
\hline 1 & 1971 & 98.9 & 8.6 & 56.8 & 10.8 & 155.6 & 19.3 \\
& & $(92.0)$ & $(8.0)$ & $(84.0)$ & $(84.0)$ & $(89.0)$ & $(11.0)$ \\
\hline 2 & 1981 & 139.8 & 14.9 & 61.0 & 12.9 & 200.5 & 27.93 \\
& & $(90.3)$ & $(9.7)$ & $(82.5)$ & $(17.5)$ & $(87.8)$ & $(12.2)$ \\
\hline 3 & 1991 & 167.1 & 23.4 & 62.4 & 14.3 & 229.5 & 37.8 \\
& & $(87.7)$ & $(12.3)$ & $(81.3)$ & $(18.7)$ & $(85.9)$ & $(14.1)$ \\
\hline
\end{tabular}

Source:DGE \& Ministry of Labour, Govt. of India, (Figures in Parenthesis represents Percentages. 
Table - 9 Work Participation Rate in India - 1971-91

\begin{tabular}{|c|c|c|c|c|c|}
\hline Sl. No. & Year & Category & \multicolumn{3}{|c|}{ Percentage } \\
\hline & & & Total & Male & Female \\
\hline$(1)$ & (2) & (3) & (4) & $(5)$ & $(6)$ \\
\hline \multirow{3}{*}{1} & \multirow{3}{*}{1971} & Total & 34.2 & 52.7 & 14.2 \\
\hline & & Rural & 35.3 & 53.8 & 15.9 \\
\hline & & Urban & 29.6 & 48.9 & 7.2 \\
\hline \multirow{3}{*}{2} & \multirow{3}{*}{1981} & Total & 36.7 & 52.6 & 19.7 \\
\hline & & Rural & 38.8 & 53.8 & 23.1 \\
\hline & & Urban & 30.0 & 49.1 & 8.3 \\
\hline \multirow{3}{*}{3} & \multirow{3}{*}{1991} & Total & 37.7 & 51.6 & 22.3 \\
\hline & & Rural & 40.2 & 52.5 & 26.8 \\
\hline & & Urban & 30.4 & 49.0 & 9.2 \\
\hline \multirow{3}{*}{4} & \multirow{3}{*}{2001} & Total & 39.2 & 51.9 & 25.7 \\
\hline & & Rural & 42.0 & 52.4 & 31.0 \\
\hline & & Urban & 32.0 & 50.9 & 11.6 \\
\hline
\end{tabular}

Source: Census of India - 1991.

Table - 9 provides information on work participation rates in India, during 1971-2001 both in the rural and urban areas. The table reveals that there exist, clear discrimination in work participation rates between males and females. The female participation rates are much lower as compared to males. It is also observed that women are the comparatively greater losers of changing technologies. The issue of women work and child care are widely debated. There is strong relationship between women's health we need to consider the totality of women's work, whether paid or unpaid or working in the organized or unorganized sectors.

\section{Women and Political Participation:}

The universal declaration of human rights declares that every one has the right to take part in the government of his or her country. The United Nations Economic and social Commission endorsed a target of 30 per cent of women at all levels of decision-making by 1995. It has been rightly remarked that although the recent years have witnessed an increase in the female voters changes in the voter participation did not change. The women who are going to participate did not improve. Globally women constitute 10 per cent of legislative bodies and less in parliament positions. In India the 1996 Lok Sabha has only 5.9 per cent of women (32 out of 544 ) and out of the total contestants only 2.9 per cent were women. Political empowerment of women does not imply just a right to vote but to discuss. In recent years there have been increased participation of women at lower centers of decision-making.

Table - 10 Gender Empowerment Measure - 1997

\begin{tabular}{|c|c|c|c|c|c|}
\hline Sl. No. & Indicator & India & $\begin{array}{c}\text { Low Human } \\
\text { Development } \\
\text { Economics }\end{array}$ & $\begin{array}{l}\text { All Developing } \\
\text { Countries }\end{array}$ & South Asia \\
\hline (1) & (2) & (3) & (4) & (5) & (6) \\
\hline 1 & $\begin{array}{c}\text { Seats in } \\
\text { Parliament } \% \text { age } \\
\text { of women }\end{array}$ & 7.3 & 7.2 & 12.7 & 6.9 \\
\hline 2 & $\begin{array}{c}\text { Administrators \& } \\
\text { Managers \% age } \\
\text { of Women }\end{array}$ & 2.3 & 3.5 & 10.0 & 2.9 \\
\hline 3 & $\begin{array}{c}\text { Professionals \& } \\
\text { Technical } \\
\text { Workers \% age }\end{array}$ & 20.5 & 21.1 & 36.7 & 21.3 \\
\hline 4 & GEM Value & 0.228 & 0.223 & 0.367 & 0.231 \\
\hline
\end{tabular}

The 73 and 74 constitutional amendments of India introduced reservation of the one third of the seats for women in Panchayati and Municipal bodies is good example of women political empowerment at the grass root level. The proposal of constitution amendment for one-third reservation of seats for women in parliament and state assemblies will be feather in the cap democratic setup.

\section{Summary and Conclusion:}

The paper has broadly discussed the issue of gender inequality, women empowerment and reproductive health among women in India. The measures under taken by the international and national organizations to improve the status of women in India were discussed at length. There is a good correlation between gender inequality and reproductive health of women. 
The sex ratio is very low in India as compared to many developing countries and most of the advanced countries. The high maternal mortality, infant mortality, child mortality foeticide, infanticide, abortion, low age of marriage social stigma associated with marriage, son preference are responsible for low sex ratio in India. Also under counting of women associated with many social factors is one of the main reasons for low sex ratio in the country.

The Social factors, such as, illiteracy, ignorance, the economic factors such as low wage, unemployment under employment and political factors such as, low participation of women in the elections and other elected bodies are also equally responsible for gender inequality in the country. So, there is every need to bring about changes in social, economic, and political structure in order to reduce gender inequality in India and empower women in its true term.

The term empowerment of women is an important popular concept among political spectrum. Empowerment through the expansion of the civil, political and social rights of citizenship is a laborious and unexciting process. Empowerment is only effective answer to oppression, exploitation, injustice, and other melodies of society. The idea of empowerment contains exciting possibilities. It is a wide term with no specific meaning. The term is very vogue and is more a context driven rather than theory driven. It is about social transformation. It is about the people rather than politicians. It is about power, although the concept of power contained in it is generally left unspecified.

Empowerment is both a means to an end and an end in it self. The focus on empowerment has given a new emphasis to the building of economic and social capabilities among individuals, classes and communities. It is theories of social change in particular, a change from a hierarchical to and egalitarian type of society. It is based on democratic society, which is based on recognition of equal rights to all individuals in its place. Empowerment appears to be an alternative path for dismantling the old structure and putting new one in this place. Empowerment is to change the society through re-arrangement of the power. So there is a need for empowerment through civic, political and social rights of citizens.

Gender empowerment measure is a measure for women development. It measures gender inequality in a society. India ranks 86 out of 175 countries in the world, as far as gender empowerment is concerned. The measure indicates whether women are able to actively participate in economic and political life. It measures the gender inequality in basic capabilities of women. It focuses on gender inequality in the key areas of social economic political scenario. The lack of access to land, to credit, better employment opportunities, handicaps women's ability to free from poverty. Poverty is more among women as compared to men. When women are disproportionately poor, they are dis-empowered and bounded by strains of productive work, the birth of children and other household and community responsibilities.

\section{Reference}

[1] Henry Shyrock et.al (1973) Methods and Materials of Demography, Vol. 1., U.S. Bureau of Census, Washington D.C., p-196 .

[2] Berta - Esteve - Volast, 2004, "Gender discrimination and Growth: Theory and Evidence from India," London, London School of Economics and Political Sciences.

[3] U.N., (1973) The Determinants and Consequences of the Population Trends, Vol. 1, ST/SOA/SCR/A/50 population studies No. 50, New York, p-271.

[4] Registrar General of India, (1972), Sex Composition in India, SRS Analytical Series, No. 4, PP 23-24.

[5] Fred, Arnold, Sunitha Kishore and T.K. Roy (2002) "Sex Selective Abortions in India" Population and Development Review, Vol28, No. 4, p-759-785.U.N. (1973) op.cit.

[6] Anna - Maria Lind, 2006, "Struggle and Development: Approaching gender bias in Practical International Development Work", Orebro, Orebro University.

[7] M.K. Premi (2001) “The Missing Girl Child” Economic and Political Weekly, May 26, pp-1875-1880.

[8] Coale (1991) "Excess female Mortality and the Balance of Sexes in Population - An Estimate of Missing females" Population and Development Review, Vol. 17, No. 3.

[9] Praveen Visaria (1961) "The Sex Ratio in Indian Population in 1961, Census of India - 1961, Monograph No. 10.

[10] Kalyani Menon Sen and A.K.Shiva Kumar, 2001, “Women in India, How Free? How Equal?”, New Delhi, UNDAF.

[11] Amarthya Sen (2001) "Many Faces of Gender Inequalities" Front Line, No. 9, pp-414.

[12] Fred, Arnold, Sunitha Kishore and T.K. Roy (2002) "Sex Selective Abortions in India" Population and Development Review, Vol28, No. 4, p-759-785.

[13] Desai, Sonalde, 1994, “Gender Inequalities and Demographic Behaviours : India”, New York, The Population Council, Inc.

[14] Julie Mullin, 2008, "Gender Discrimination - Why is it still so bad and what can you do about it?", Accessed from www.childerninneed.org on 15.08.2008. 